\title{
SEPARATION AND ANALYSIS OF AMLODIPINE/BENAZEPRIL COMBINATION IN CAPSULES BY A NOVEL ION PAIR LIQUID CHROMATOGRAPHY
}

\author{
SALEH TREFI*, YASER BITAR \\ Quality of Medicines and Pharmaceutical Chemistry Department-Faculty of Pharmacy-University of Aleppo-Syria \\ Email: trefi76@yahoo.fr
}

Received: 10 Sep 2018 Revised and Accepted: 04 Dec 2018

\section{ABSTRACT}

Objective: The objective of this study was to develop and validate a novel ion-pair liquid chromatography method, in order to separate and assay of amlodipine/benazepril combination in capsules. This method was a fast, practical and additional choice in quality control laboratories.

Methods: The chromatographic conditions comprised of a classical $\mathrm{C}_{18}$-type stationary phase $(250 \times 4.6 \mathrm{~mm}, 5 \mu)$, with a mobile phase consisting of: $45 \%$ of $10^{-3} \mathrm{M}$ of cetrimide and $55 \%$ acetonitrile. The flow rate was $1 \mathrm{ml} / \mathrm{min}$; the detection wavelength was at $242 \mathrm{~nm}$, under ambient temperature.

Results: The method was validated for linearity with correlation coefficients very close to one, the accuracy with mean recovery values between 95.0-105.0\%, precision with relative standard deviations of the calculated concentrations less than $5.0 \%$ and specificity in the presence of degradation products and excipients.

Conclusion: The results presented in this paper showed that the developed method was fast and applicable, for the separation and determination of amlodipine/benazepril combination in capsules.

Keywords: HPLC, Ion pair liquid chromatography, Amlodipine, Benazepril

(c) 2019 The Authors. Published by Innovare Academic Sciences Pvt Ltd. This is an open access article under the CC BY license (http://creativecommons.org/licenses/by/4.0/) DOI: http://dx.doi.org/10.22159/ijpps.2019v11i1.29672

\section{INTRODUCTION}

Amlodipine besilate (fig. 1) 3-Ethyl 5-methyl (4RS)-2-[(2aminoethoxy) methyl]-4-(2-chlorophenyl)-6-methyl-1,4-dihydropyridine-3,5-dicarboxylate benzenesulfonate is a long-acting calcium channel blocker, used as an anti-hypertensive and in the treatment of angina. Like other calcium channel blockers, amlodipine acts by relaxing the smooth muscle in the arterial wall, decreasing total peripheral resistance and hence reducing blood pressure; in angina, it increases blood flow to the heart muscle.

It is also a second-generation 1, 4-dihyropyridine derivative of the prototypical molecule nifedipine. Like most of the secondgeneration dihydropyridine derivatives, it has greater selectivity for the vascular smooth muscle than myocardial tissue, a longer half-life $(34 \mathrm{~h})$, and less negative inotropy than the prototypical nifedipine. Amlodipine is used in the treatment of chronic stable angina and in the management of mild-moderate hypertension. It is marketed as the benzene sulfonic acid salt.

Benazepril Hydrochloride (fig. 1) [(3S)-3-[[(1S)-1-(Ethoxycarbonyl)-3phenylpropyl]amino]-2-oxo-2,3,4,5-tetrahydro-1H-1-benzazepin-1-yl] acetic acid hydrochloride is an antihypertensive drug, which belongs to the group of angiotensin convertase inhibitors. It acts on the reninangiotensin-aldosterone system, by inhibition of the conversion of the inactive angiotensin 1 to the highly potent vasoconstrictor-angiotensin 2. It also reduces the degradation of bradykinin. Benazepril is applied in pharmacotherapy as a first choice drug for the treatment of arterial hypertension, ischemic heart disease, hypertrophy of the left heart ventricle and postinfarction heart dysfunction [1]

The combination of amlodipine besylate and benazepril $\mathrm{HCl}$ is very useful in the treatment of hypertension, the brand name of this oral combination is Lotrel which is developed by Novartes.<smiles>CCOC(=O)C1=C(COCCN)NC(C)=C(C(=O)OC)[C@H]1c1ccccc1Cl</smiles><smiles>CCOC(=O)[C@H](CCc1ccccc1)N[C@H]1CCc2ccccc2N(CC(=O)O)C1=O</smiles><smiles>Cl</smiles>

Fig. 1: Chemical structures of amlodipine besilate/benazepril hydrochloride [2]

Many chromatographic methods for analyzing amlodipine/benazepril combination in pharmaceutical formulations, were reported in the bibliography [3-9].

There were also, other articles describing the use of HPLC methods in order to analyze amlodipine and benazepril and some of their combinations with other pharmaceutical ingredients [10-14].
The previous HPLC methods used different mobile phases with different parameters. All of these methods used a classical elution with buffers. For this reason, we decided to propose a novel ion-pair HPLC method. This proposed method may be applied to determine these drugs with some advantages. The use of cetrimide as a surfactant in the mobile phase, instead of buffers improves its flow through the HPLC chain and reduces problems of precipitation of 
salts on the pumps, arising from the use of buffers. This technic of elution using a surfactant such as cetrimide diminish the pression applied on the column.

In addition, we must update the analytical methods in a regular manner in quality control laboratories, in order to choose the best one.

Therefore, the objective of this work was to develop and validate a novel ion-pair HPLC method, for the assay amlodipine/benazepril in capsules.

To our knowledge, this is the first ion-pair liquid chromatography that used cetrimide as a surfactant, to determine amlodipine/benazepril.

\section{MATERIALS AND METHODS}

\section{Chemicals and reagents}

Working standards of amlodipine/benazepril were gifted by Ultra Medica pharmaceutical industries, Damascus-Syria. The capsules (brand name-Norkand and Lowcor plus), as received, were stored in the dark at ambient temperature and humidity. They were all analyzed within expiry dates. All the other used reagents were of HPLC grade: acetonitrile (PROLABO), cetrimide (TCI Chemicals), deionized water for HPLC and syringe filters $0.45 \mu \mathrm{m}$.

\section{Instrumentation}

The HPLC instruments used were an Agilent 1260 infinity, equipped with a UV detector and a Shimadzu LC 20-AT with a diode array detector. The $\mathrm{pH}$ meter used was from Crison.

Method development and optimization of chromatographic conditions

\section{Selection of detection wavelength}

The utilized detection wavelength was at $242 \mathrm{~nm}$.

\section{Column selection}

A NUCLEODUR-C18ec-Machrey-Nagel reversed phase column, $250 \mathrm{x}$ $4.6 \mathrm{~mm}$ 5-Micron was utilized.

\section{Mobile phase preparation}

The mobile phase is consisting of: $45 \%$ of $10^{-3} \mathrm{M}$ cetrimide and $55 \%$ acetonitrile, and apparent $\mathrm{pH}$ was 10.0 without adding any buffer.

\section{Reference solutions preparation}

A precise quantity of the working standards was accurately weighed, then dissolved in a sufficient volume of distilled water, to obtain the starting standard solutions: $10 \mathrm{mg} / 50 \mathrm{ml}$ water of benazepril, 5 $\mathrm{mg} / 50 \mathrm{ml}$ water of amlodipine. These starting standard solutions were used for the preparation of the linearity solutions.

\section{Tablet samples preparation}

Twenty capsules of Norkand 10 (amlodipine $5 \mathrm{mg} /$ benazepril 10 $\mathrm{mg}$ ), were emptied, then a quantity of the powder containing 2 capsules was transferred into a $100 \mathrm{ml}$ volumetric flask containing deionized water, the content was dispersed under magnetic stirring during $20 \mathrm{~min}$ and sonicated for $10 \mathrm{~min}$, until the tow active pharmaceutical ingredients were well dissolved ( $\mathrm{C}=5 \mathrm{mg}$ amlodipine $/ 100 \mathrm{ml})$ and $(\mathrm{C}=10 \mathrm{mg}$ benazepril $/ 100 \mathrm{ml})$.

The same precedent protocol was applied, in order to prepare Lowcor plus (amlodipine $5 \mathrm{mg} /$ benazepril $20 \mathrm{mg}$ ).

Later, the tablets solution prepared as mentioned above (Norkand 10 ), was standing at room temperature and sunlight for $60 \mathrm{~d}$. Then, it was analyzed for specificity test demonstration.

\section{Analytical method validation}

Method validation was performed under a variety of international regulations and quality standards, for the validation of pharmaceutical analytical methods [15-18].

\section{RESULTS AND DISCUSSION}

\section{HPLC analysis}

The chromatographic conditions comprised of a C18 reversed phase column, $250 \times 4.6 \mathrm{~mm} 5$-Micron, with a mobile phase consisting of: $45 \%$ of $10^{-3} \mathrm{M}$ of cetrimide and $55 \%$ acetonitrile.

The flow rate was $1 \mathrm{ml} / \mathrm{min}$, the utilized detection wavelength was $242 \mathrm{~nm}$, under ambient temperature.

A solution containing a mixture $1 / 1$ of the reference solutions was injected under the previous chromatographic conditions, the retention times were amlodipine $3.12 \mathrm{~min}$, benazepril 5.8 min (fig. 2).

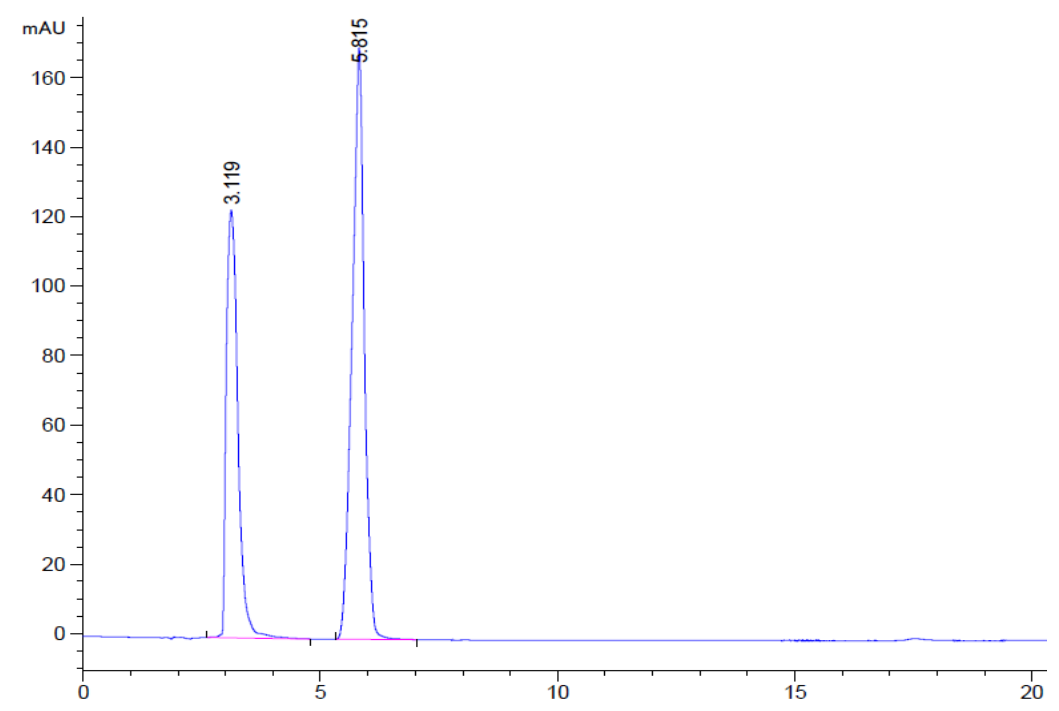

Fig. 2: Chromatogram of a standard solution containing a mixture of amlodipine/benazepril

\section{Analytical method validation}

\section{Linearity}

The linearity of analytical procedure: is its ability (within a given range) to obtain test results, which are directly proportional to the concentration of an analyte in the sample, It may be demonstrated directly on the analyte, or on spiked samples using at least five concentrations over the whole working range [15-18].

The linearity was evaluated by linear regression analysis, which was calculated by the least square regression method. Five concentrations over the working range were prepared for each drug; this process was done three different times during three weeks 
$(n=3)$. (fig. 3) showed the regression lines of amlodipine/benazepril with the correlation coefficients $\left(\mathrm{R}^{2}\right)$ given in table 1 . All the correlation coefficients were very close to one, so the developed method was linear for analyzing the tow drugs.
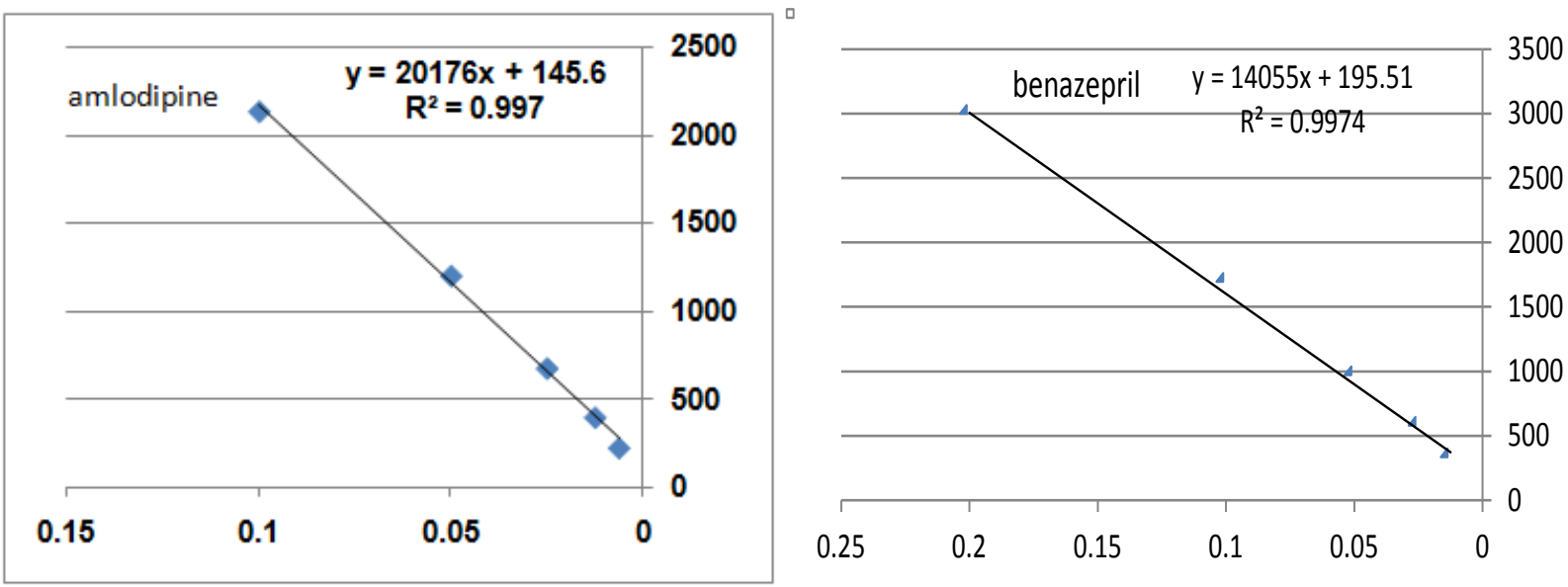

Fig. 3: Linearity lines of amlodipine/benazepril

Table 1: Correlation coefficients of amlodipine/benazepril

\begin{tabular}{lll}
\hline & Amlodipine & Benazepril \\
\hline Correlation coefficients $^{\mathrm{a}}\left(\mathrm{R}^{2}\right)$ & $\mathrm{R}^{2}=0.997$ & $\mathrm{R}^{2}=0.997$ \\
Equation $^{\mathrm{a}}$ & $\mathrm{y}=20176 \mathrm{x}+145.620$ & $\mathrm{y}=14055 \mathrm{x}+195.51$ \\
\hline
\end{tabular}

${ }^{a} n=3$ : five concentrations over the working range, were prepared for each drug; this process was done three different times during three weeks.

\section{Range}

The range of an analytical procedure is the interval between the upper and lower concentration (amounts) of analyte in the sample (including these concentrations), for which it has been demonstrated that the analytical procedure has a suitable level of precision, accuracy, and linearity [15-18].

The linearity was demonstrated in the interval $(0.1-0.00625 \mathrm{mg} / \mathrm{ml})$ for amlodipine, (0.2-0.0125 $\mathrm{mg} / \mathrm{ml})$ for benazepril.

\section{Accuracy}

The accuracy of an analytical procedure: expresses the closeness of agreement between the value which is accepted, either as a true conventional value or an accepted reference value and the value found. For the quantitative approaches, at least nine determinations across the specified range should be obtained; for example, three replicates at three concentration levels each. The percentage recovery or the difference between the mean and the accepted true value together with the confidence intervals are recommended [15-18].

Three concentration levels $(0.1,0.05$, and $0.025 \mathrm{mg} / \mathrm{ml})$ have been used to study the accuracy of amlodipine. The results indicated that the individual recovery ranged from $97.72 \%$ to $102.98 \%$. The recovery of amlodipine by the proposed method was accepted, as the mean recovery value was 100.82 between $95.0-105.0 \%$ with RSD value 2.73 not more than $5.0 \%$.

Three concentration levels also $(0.1,0.05$, and $0.025 \mathrm{mg} / \mathrm{ml}$ ) have been used to study the accuracy of benazepril. The individual recovery ranged from $100.12 \%$ to $106.19 \%$. The recovery of benazepril by the proposed method was accepted, as the mean recovery value 103.57 was between $95.0-105.0 \%$ with $\mathrm{RSD}$ value 3.00 not more than $5.0 \%$.

Table 2: Mean recoveries of three concentration levels of amlodipine/benazepril

\begin{tabular}{|c|c|c|c|}
\hline & Amlodipine & & Benazepril \\
\hline Mean concentration level ${ }_{1}(0.1 \mathrm{mg} / \mathrm{ml}) \%^{a}$ & 97.72 & Mean concentration level ${ }_{1}(0.1 \mathrm{mg} / \mathrm{ml}) \%^{a}$ & 104.39 \\
\hline Mean concentration level $2(0.05 \mathrm{mg} / \mathrm{ml}) \%^{\mathrm{a}}$ & 102.98 & Mean concentration level $2(0.05 \mathrm{mg} / \mathrm{ml}) \%^{\mathrm{a}}$ & 106.19 \\
\hline Mean concentration level $3(0.025 \mathrm{mg} / \mathrm{ml}) \% \mathrm{a}$ & 101.75 & Mean concentration level $3(0.025 \mathrm{mg} / \mathrm{ml}) \% \mathrm{a}$ & 100.12 \\
\hline Mean recovery $\%( \pm)$ SD & $100.82 \pm 2.75$ & Mean recovery $\%( \pm)$ SD & $103.57 \pm 3.11$ \\
\hline RSD & 2.73 & RSD & 3.00 \\
\hline
\end{tabular}

${ }^{a}$ mean, $\mathrm{n}=3$

\section{Precision}

The precision of an analytical procedure expresses the closeness of agreement between a series of measurements obtained from multiple sampling of the same homogeneous sample under the prescribed conditions. Various precision levels are system or instrument precision, intermediate precision, repeatability, reproducibility.

Repeatability, this short-term variability includes, in addition to the system precision, the contributions from the sample preparation, such as weighing, aliquoting, dilution, extraction, homogenization, etc.
Intermediate precision includes the influence of additional random effects according to the intended use of the procedure, in the same laboratory and can be regarded as an (initial) estimate for the longterm variability. Relevant factors, such as operator, instrument, and days should be varied. Reproducibility, according to the ICH definition is obtained varying further factors between laboratories and is particularly important in the assessment of official' compendial methods or if the method is applied at different sites [15-18].

Repeatability and intermediate precision results: The solutions 0.1 $\mathrm{mg} / \mathrm{ml}$ of amlodipine, $0.1 \mathrm{mg} / \mathrm{ml}$ of benazepril have been prepared at 
three different times, by three analysts during three weeks, each solution was injected three times $(\mathrm{N}=9)$. Relative standard deviations of the calculated concentrations (RSD) were given in table 3 .

The RSD of the nine determinations of solutions $(0.1 \mathrm{mg} / \mathrm{ml})$ of amlodipine/benazepril, were $1.8 \%$ and $1.27 \%$ for benazepril, (not more than $2.0 \%$ ). These results indicated that the repeatability and intermediate precision of this method were correct for both amlodipine/benazepril.

\section{Limit of detection (LOD) and limit of quantitation (LOQ)}

Limit of detection: is the lowest amount of an analyte in a sample which can be detected but not necessarily quantified as an exact value. Limit of quantitation is the lowest concentration of an analyte in a sample which can be quantitatively determined with suitable precision and accuracy [15-18]. The calculated LODs and LOQs for amlodipine/benazepril, by this new method, were mentioned in table 4

Table 3: Relative standard deviation of the nine determinations of solutions of amlodipine/benazepril

\begin{tabular}{lll}
\hline $\mathbf{N}$ & Amlodipine $(\mathbf{0 . 1} \mathbf{~ m g} / \mathbf{m l})$ & Benazepril (0.1 mg/ml) \\
\hline 1 & 0.0956 & 0.0616 \\
2 & 0.0956 & 0.0611 \\
3 & 0.0955 & 0.0612 \\
4 & 0.0976 & 0.0597 \\
5 & 0.0976 & 0.0592 \\
6 & 0.0980 & 0.0604 \\
7 & 0.0999 & 0.0599 \\
8 & 0.0998 & 0.0606 \\
9 & 0.0994 & 0.0597 \\
aMean( \pm )SD & $0.0977 \pm 0.0017$ & $0.0604 \pm 0.000771$ \\
RSD & 1.82 & 1.27 \\
\hline
\end{tabular}

$\mathrm{a}_{\mathrm{n}}=9$

Table 4: Limit of detection and quantification of the HPLC method

\begin{tabular}{lll}
\hline & Amlodipine $(\mathbf{m g} / \mathbf{m l})$ & Benazepril (mg/ml) \\
\hline Limit of detection & 0.062 & 0.037 \\
limit of quantitation & 0.187 & 0.114 \\
\hline
\end{tabular}

\section{Specificity}

Specificity is the ability to assess the analyte unequivocally in the presence of components, which may be expected to be present. Typically, these might include impurities, degradants, matrix, etc. [15-18].

The chromatogram of the tablets solution before degradation indicated no additional peaks other than those of amlodipine 2.9 min/benazepril 5.9 min (fig. 4).
In order to demonstrate the specificity of the method, tablets solution was exposed to sunlight for $60 \mathrm{~d}$ at room temperature. Then, it was recorded.

The chromatogram of the standing tablets solution of amlodipine/ benazepril showed many additional peaks (3, 3.70, 4.34, 6.65 and $9 \mathrm{~min})$, but they were well resolved from the two main peaks 2.6 for amlodipine and 5.5 for benazepril. (fig. 5). So, the developed method is able to assess amlodipine/benazepril unequivocally in the presence of degradation products and the excipients.

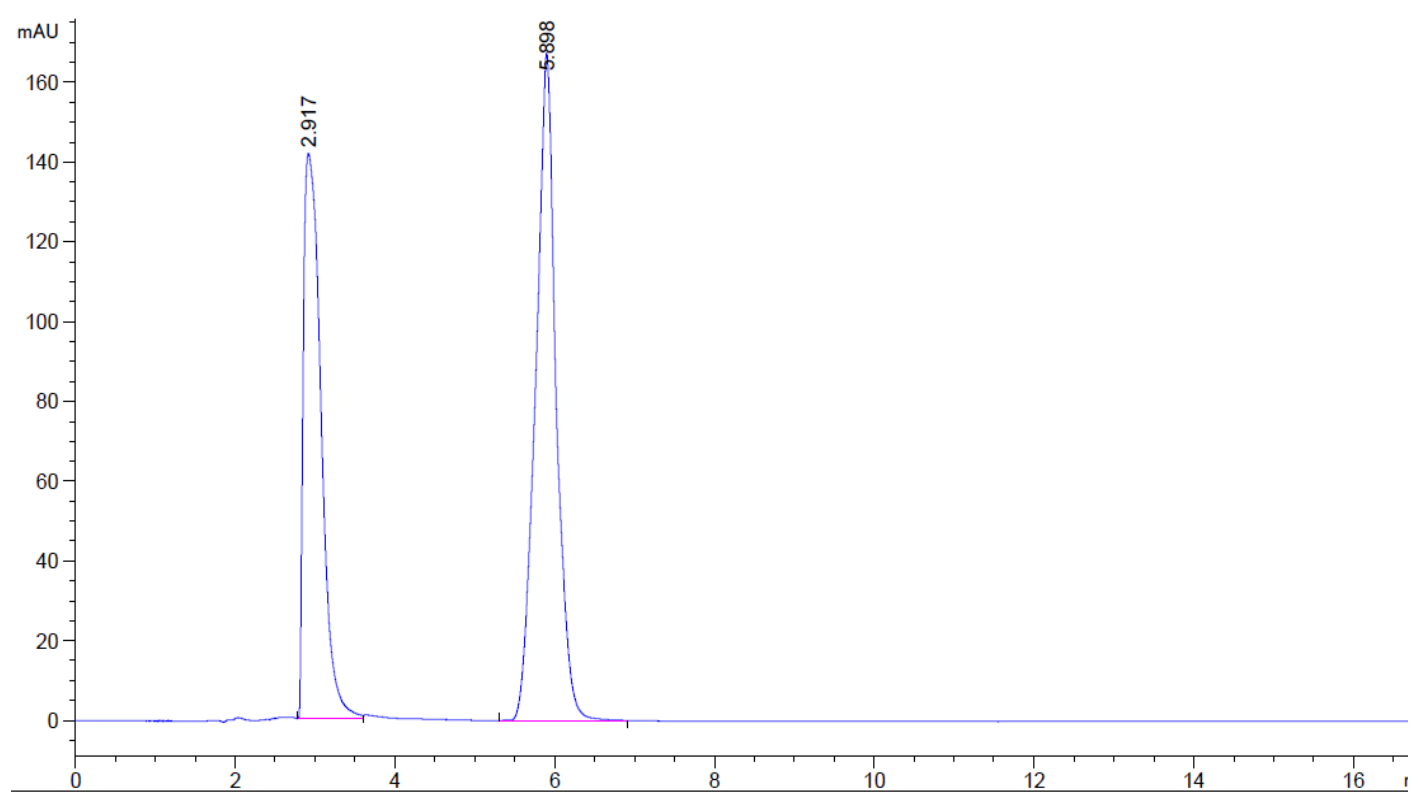

Fig. 4: Chromatograms of the standing tablets solution of amlodipine/benazepril before degradation 


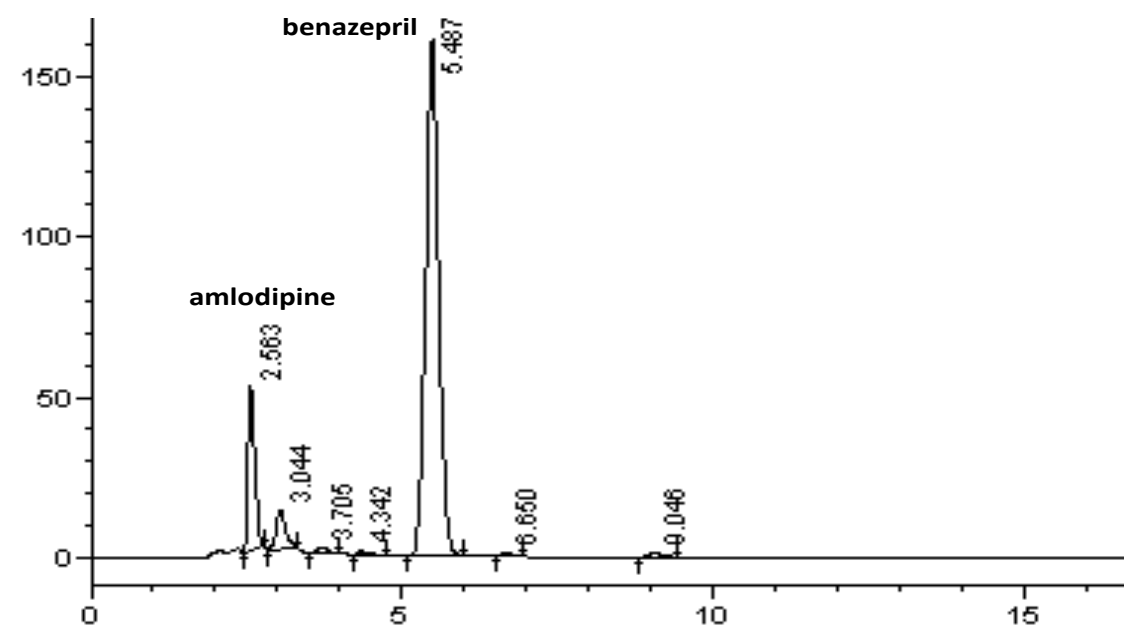

Fig. 5: Chromatogram of the standing tablets solution of amlodipine/benazepril after degradation

\section{Tablets assay}

Finally, we applied our method to commercial assay capsules purchased from Syria. The data of capsules contents were reported in table 5. The specification of the USP Pharmacopeia recommended that capsules should contain not less than $90 \%$ and not more than $110 \%$ of the labeled amount of the active pharmaceutical ingredient for amlodipine and benazepril [19]. Amlodipine and benazepril of Syrian capsules contained the active pharmaceutical ingredient, within the range $90-110 \%$ of the stated concentration with RSD not more than 5\%. Norkand 10 contained $95.39 \%$ amlodipine/105.76\% benazepril, Lowcor plus 5/20 contained $104.60 \%$ amlodipine/ $92.59 \%$ benazepril, Norkand 20 contained $100.00 \%$ amlodipine/ $101.64 \%$ benazepril. These results reported herein demonstrated that the quality of capsules of amlodipine/benazepril sold in Syria was correct.

Abhi Kavantha et al. results of assaying amlodipine/benazepril tablets were $98.00 \pm 1.89$ for amlodipine and $99.04 \pm 1.62$ for benazepril [3]. Hemdan A et al. result of assaying amlodipine/ benazepril capsules was $100.45 \pm 0.248$ for benazepril and $99.86 \pm 0.485$ for amlodipine [4]. Safwan Ashour et al. results of analyzing capsules purchased in Syria, by their proposed method were between $99.76 \pm 1.11$ and $101.84 \pm 1.26$ for benazepril and between $102.06 .76 \pm 1.30$ and $105.47 \pm 0.71$ for amlodipine [5]

Our results of assaying capsules were in accordance with their of the president studies.

Table 5: Results of tablets assay by the developed HPLC method

\begin{tabular}{|c|c|c|c|c|c|c|}
\hline $\begin{array}{l}\text { Formulation } \\
\text { name }\end{array}$ & $\begin{array}{l}\text { Active ingredient and } \\
\text { potency }\end{array}$ & $\begin{array}{l}\text { Batch } \\
\text { number }\end{array}$ & $\begin{array}{l}\text { Manufacturer } \\
\text { name }\end{array}$ & $\begin{array}{l}\text { \% of nominal concentration } \\
\text { amlodipine /benazepril }\end{array}$ & $\begin{array}{l}\text { SD amlodipine } \\
\text { /benazepril }\end{array}$ & $\begin{array}{l}\text { RSD amlodipine } \\
\text { /benazepril }\end{array}$ \\
\hline Norkand 10 & $\begin{array}{l}\text { amlodipine } 5 \\
\mathrm{mg} / \text { benazepril } 10 \mathrm{mg}\end{array}$ & F1952 & $\begin{array}{l}\text { Ultra Medica- } \\
\text { Syria }\end{array}$ & $95.39 / 105.76$ & $2.06 / 0.33$ & $2.16 / 0.31$ \\
\hline $\begin{array}{l}\text { Lowcor plus } \\
5 / 20\end{array}$ & $\begin{array}{l}\text { amlodipine } 5 \\
\mathrm{mg} / \text { benazepril } 20 \mathrm{mg}\end{array}$ & 0026 & $\begin{array}{l}\text { National } \\
\text { Company-Syria }\end{array}$ & $104.60 / 92.59$ & $0.049 / 0.058$ & $0.047 / 0.063$ \\
\hline Norkand 20 & $\begin{array}{l}\text { amlodipine } 5 \\
\mathrm{mg} / \text { benazepril } 20 \mathrm{mg}\end{array}$ & 62211 & $\begin{array}{l}\text { Ultra Medica- } \\
\text { Syria }\end{array}$ & $100.00 / 101.64$ & $0.90 / 0.032$ & $0.90 / 0.031$ \\
\hline
\end{tabular}

an $=3$

\section{CONCLUSION}

A novel ion-pair HPLC method has been developed for the determination of amlodipine/benazepril in capsules. This method was utilized to separate a mixture of amlodipine/benazepril in capsules and to determine the quantity of the tow active ingredients as declared on the label. This method could be an additional analytical technique particularly in the quality control of raw materials, active pharmaceutical ingredients and pharmaceutical formulations.

\section{ACKNOWLEDGMENT}

This research work was supported by the University of Aleppo.

\section{AUTHORS CONTRIBUTIONS}

The study was carried out in collaboration among all the authors. The idea was developed by Saleh Trefi and Yaser Bitar, the analysis was done by Saleh Trefi and Yaser Bitar, optimization was done by Yaser Bitar. The manuscript was written by Saleh Trefi.

\section{CONFLICT OF INTERESTS}

There is no conflict of interest between authors.

\section{REFERENCES}

1. Block JH, Beale JM. Wilson, Gisvold's. textbook of organic medicinal and pharmaceutical chemistry. 11th ed. Philadelphia: Lippincott Williams and Wilkins; 2004. p. 622-75.

2. British Pharmacopeia Online; 2015.

3. Abhi K, Manju M. Development and validation of RP-HPLC and UV-spectrophotometric methods for rapid simultaneous estimation of amlodipine and benazepril in pure and fixed dose combination. Arab J Chem 2017;10:s3021-28.

4. Hemdan A, Omar AE, Farouk M, Shereen MT, Mostafa AS Development of validated stability indicating RP-HPLC method for simultaneous determination of benazepril, benaziprilate, and amlodipine in the presence of their degradation products and application to the pharmaceutical formulation and human plasma. Colloids Surf B 2016;16:112.

5. Ashour S, Alhaj Sakur A, Kudemati MA. Validated stability is indicating a liquid chromatographic method for the simultaneous determination of amlodipine and benazepril in capsules dosage form. Canadian Chem Trans 2014;2:418-33.

6. Rama JVE, Gopichant I, Venkatasubramanian J, Raghuram P, Sudhakar RV, Jadi SR. New stability indicating for 
quantification of impurities in amlodipine and benazepril capsules by validated HPLC. Am J Anal Chem 2013;4:715-24.

7. Sarat M, Murali Krishna P, Rambabu C. Development and validation of RPHPLC method for simultaneous estimation of amlodipine besylate and benazepril $\mathrm{HCl}$ in the tablet dosage form. Int J Curr Pharm Res 2012;4:80-4.

8. Gajanan BK, Mazahar NF. Simultaneous determination of amlodipine and benazepril hydrochloride in pharmaceutical dosage form by LC. Anal Sci 2009;25:1495-8.

9. Naidu KR, Kale UN, Shingare MS. Stability indicating RP-HPLC method for simultaneous determination of amlodipine and benazepril hydrochloride from their combination drug product. J Pharm Biomed Anal 2005;39:147-55.

10. Osman RAM, Elbashir AA. A high-performance liquid HPLC method for simultaneous the determination of amlodipine drug in dosage form using1,2-naphthoquine-4-sulfonate. J Anal Pharm Res 2017;6:163-70.

11. Chitlange SS, Imran M, Sakarkar DM. RP-HPLC method for simultaneous estimation of amlodipine and metoprolol in tablet formulation. Asian J Pharm 2008;4:232-4.

12. Celebier M, Kaynak MS, Altinoz S, Sahin S. HPLC method for the simultaneous analysis of amlodipine and valsartan in combined dosage forms and in vitro dissolution studies. Braz J Pharm Sci 2010;46:761-8.
13. Hafez HM, Elshanawany AA, Abdelaziz LM, Mohram MS Development of a stability-indicating HPLC method for simultaneous determination of amlodipine besylate and atorvastatin calcium in bulk and pharmaceutical dosage form. Pharm Anal Acta 2014;5:316-5.

14. Chhalotiya UK, Varsha LP, Dimal AS, Kashyap KB, Sunil LB. Stability-indicating LC method for the estimation of benazepril $\mathrm{HCl}$ and hydrochlorothiazide in the pharmaceutical dosage form. J Chrom Sep Tech 2014;5:216-22.

15. http://www.ich.org/fileadmin/Public_Web_Site/ICH_Products /Guidelines/Quality/Q2_R1/Step4/Q2_R1_Guideline.pdf. [Last accessed on 10 Aug 2018].

16. Taverniers I, De loose M, Van Bockstaele E. Trends in quality in the analytical laboratory. II. Analytical method validation and quality assurance. Trends Anal Chem 2004;23:535-52.

17. Taverniers I, Van Bockstaele E, De loose M. Trends in quality in the analytical laboratory. I. traceability and measurement uncertainty of analytical results. Trends Anal Chem 2004;23:480-90

18. Ermer J, Miller JH Mc. Method validation in pharmaceutical analysis. WILEY-VCH Verlag GmbH and Co. KGa A, Weinheim; 2005.

19. United Stated Pharmacopoeia USP 38/National Formulary NF 33; 2015. 